\title{
PENERAPAN PROBLEM BASED LEARNING UNTUK MENINGKATKAN AKTIVITAS BELAJAR DAN HASIL BELAJAR BIOLOGI SISWA SMA
}

\section{IMPLEMENTATION OF PROBLEM BASED LEARNING TO IMPROVE LEARNING ACTIVITIES AND BIOLOGY LEARNING OUTCOMES OF HIGH SCHOO STUDENTS}

\author{
Tami Subekti ${ }^{1}$, Suwarto ${ }^{2}$, Anwari Adi Nugroho ${ }^{3}$ \\ ${ }^{123}$ Program Studi Pendidikan Biologi, Universitas Veteran Bangun Nusantara Sukoharjo \\ *Corresponding author: subektitami1@gmail.com \\ Manuscript received: ......... Revision accepted:
}

\begin{abstract}
This study aims to improve student activity and learning outcomes by using the Problem Based Learning (PBL) model in the XI grade of Mathematics and Natural Sciences at Veterans 1 Sukoharjo in the 2018/2019 academic year. This type of research is Classroom Action Research (CAR) which consists of 3 cycles, each cycle including planning, implementing, observing, reflecting. Data collection techniques using 1) observations, 2) assessment tests, 3) student observation sheets and 4) documentation. The results showed that the learning activities of cycle I were $21 \%$, cycle II $60 \%$, and cycle III $86 \%$. Learning outcomes show that the first cycle was $47 \%$ (11 students), second cycle was $65 \%$ (15 students), and third cycle was $83 \%$ (19 students). Based on the results of the study it can be concluded that the PBL model can increase learning activities and biology learning outcomes in class XI students of Veterans 1 Sukoharjo.
\end{abstract}

Keywords: Learning activities, Learning outcomes, Problem Based Learning

\section{PENDAHULUAN}

Biologi sebagai ilmu memiliki kekhasan tersendiri dibandingkan dengan ilmu-ilmu yang lain. Biologi merupakan salah satu ilmu pengetahuan yang mempelajari makhluk hidup dan kehidupannya dari berbagai aspek persoalan dan tingkat organisasinya. (Sudjoko, 2001: 2).

Pembelajaran biologi pada hakikatnya merupakan suatu proses untuk menghantarkan siswa ke tujuan belajarnya, dan biologi itu sendiri berperan sebagai alat untuk mencapai tujuan tersebut. Biologi sebagai ilmu dapat diidentifikasikan melalui objek, benda alam, persoalan/gejala yang ditunjukkan oleh alam, serta proses keilmuan dalam menemukan konsep-konsep biologi. Kurikulum 2013 adalah kurikulum yang melakukan penyederhanaan, dan tematik-integratif, menambah jam pelajaran dan bertujuan untuk mendorong peserta didik atau siswa, mampu lebih baik dalam melakukan observasi, bertanya, bernalar, dan mengkomunikasikan (mempresentasikan), apa yang mereka peroleh atau mereka ketahui setelah menerima materi pembelajaran dan diharapkan siswa kita memiliki kompetensi sikap, keterampilan, dan pengetahuan jauh lebih baik. Keberadaan Kurikulum 2013 seharusnya dimaknai sebagai bagian dari dinamika sebuah kurikulum, sebab sebagai guru yang profesional dituntut untuk selalu adaptif terhadap setiap perubahan dan peka pada kebutuhan zaman. Memiliki pemahaman yang baik tentang hakikat pembelajaran dan karakteristik materi biologi akan membantu keberhasilan implementasi Kurikulum 2013, sebab jika dicermati hakikat pembelajaran dan karakteristik materi biologi sangat relevan dengan substansi Kurikulum 2013.

Namun pada kenyataannya pembelajaran Biologi di SMA Veteran 1 Sukoharjo belum sesuai dengan pembelajaran biologi ideal berdasarkan kurikulum 2013. Hasil observasi terhadap aktivitas dan hasil belajar kognitif di kelas XI MIPA dengan KKM 70. Presentase ketuntasan aktivitas belajar siswa kelas XI MIPA 34\% dari 23 siswa. Prosentase ketuntasan hasil belajar kognitif siswa kelas XI MIPA 30\% dari 23 siswa.

Berdasarkan permasalahan di kelas XI MIPA maka pokok permasalahannya adalah aktivitas dan hasil belajar biologi yang rendah dan akar permasalahannya pada pembelajaran biologi yang tidak sesuai dengan kurikulum 2013. Sehingga solusinya adalah Penelitian Tindakan Kelas dengan menggunakan model $P B L$.

Problem based learning adalah pembelajaran yang menggunakan masalah nyata (autentik) yang tidak terstruktur (ill-structured) dan bersifat terbuka sebagai konteks bagi peserta didik untuk mengembangkan ketrampilan menyelesaikan masalah dan berfikir kritis serta sekaligus membangun pengetahuan baru (Muhammad Fathurrohman, 2015: 112).

$P B L$ adalah salah satu model pembelajaran yang dapat menyediakan lingkungan belajar yang mendukung berpikir kritis. $\mathrm{P} B L$ didasarkan pada situasi bermasalah yang membingungkan. Permasalahan tersebut akan membangkitkan rasa ingin tahu siswa, sehingga siswa 
akan tertarik untuk menyelidiki permasalahan. Pada saat siswa melakukan penyelidikan, maka siswa menggunakan tahapan berpikir kritis untuk menyelidiki masalah, menganalisa berdasarkan bukti dan mengambil keputusan berdasarkan hasil penyelidikan, hal tersebut dapat meningkatkan aktivitas mental siswa (Nafiah \& Suyanto, 2014).

Model (PBL) mengajak siswa agar mampu melatih kemampuan siswa dalam memecahkan masalah sehingga dapat meningkatkan kemampuan berpikir kritis siswa (Menurut Setyorini. U; Sukiswo; Subali, 2011).

Secara umum dapat dikemukakan bahwa kekuatan dari penerapan metode PBL/PBI ini antara lain : Siswa akan terbiasa menghadapi masalah (problem posing) dan merasa tertantang untuk menyelesaikan masalah, tidak hanya terkait dengn pembelajaran dalam kelas, tetapi juga menghapi masalah yang ada dalam kehidupan sehari-hari (real word). Memupuk solidaritas sosial dengan terbiasa berdiskusi dengan teman-teman sekelompok kemudian berdiskusi dengan teman-teman sekelasnya. Makin mengakrabkan guru dengan siswa karena ada kemungkinan suatu masalah harus diselesaikan siswa melalui eksperimen hal ini juga akan membiasakan siswa dalam menerapkan metode eksperimen (Warsono \& Haryanto, 2017)

\section{METODE PENELITIAN}

Jenis Penelitian ini adalah Penelitian Tindakan Kelas (PTK). Penelitian ini terdiri dari 3 siklus, dimana dalam satu siklus tindakan meliputi, perencanaan, pelaksanaan, observasi dan refleksi. Skema penelitian tindakan kelas dapat dilihat pada gambar 1 .

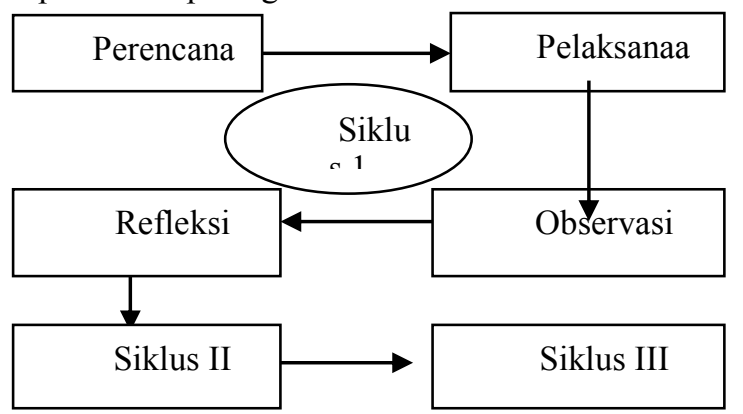

Gambar 1. Skema Penelitian Tindakan Kelas

Kegiatan penelitian dilaksanakan pada semester genap tahun pelajaran 2018/2019 dari bulan Mei dari tanggal 3 sampai tanggal 20. Jumlah siswa 23 yaitu 11 perempuan dan 12 laki-laki. Sumber data pada penelitian ini diperoleh dari dokumen mengenai data siswa dan diperoleh data hasil kognitif dari tes. Prosedur pengumpulan data pada penelitian ini dengan menggunakan dokumentasi, tes dan lembar observasi. Instrumen penelitian berupa Silabus, RPP, dan soal post test (20 soal pilihan ganda). Teknik analisis data pada penelitian ini dengan menggunakan deskriptif komparatif. Indikator keberhasilan pada penelitian ini adalah aktivitas belajar $75 \%$ ( 17 siawa) dan hasil belajar kognitif 80\% (18 siswa tuntas KKM).

\section{HASIL DAN PEMBAHASAN}

Penelitian Tindakan Kelas ini dilaksanakan di SMA Veteran 1 Sukoharjo pada bulan Mei 2019. Penilitian ini terdiri dari tiga siklus, siklus pertama dengan sistem oragan dan fungsi pencernaan, mekanisme sistem pencernaan, siklus kedua dengan materi volume udara pernapasan, mekanisme pertukaran oksigen dan karbondioksida, dan energi pernapasan pada manusia, dan siklus ketigadengan materi faktor yang mempengaruhi frekuensi dan gangguan sistem pernapasan pada manusia. Berikut hasil dan pembahasan kegiatan setiap siklus

\section{Siklus I}

Siklus I dilaksanakan pada Senin, 9Mei 2019. Dengan alokasi waktu 2 x 45 menit pada jam ke $4(9.30-10.15)$ dan jam ke 5 (10.15- 11.00). Materi yang disampaikan adalah struktur dan fungsi alat-alat respirasi serta mekanisme pernapasan. Proses pembelajaran dilakukan oleh guru biologi dan peneliti menggunakan satu observer sebagai pengamat dalam proses pembelajaran. Adapun rincian pembelajarannya sebagai berikut:

Kegiatan yang pertama adalah Kegiatan pendahuluan ini dilakukan selama 10 menit dari jam 09.30-09.40. Pada kegiatan pendahuluan sebagian siswa sudah siap dalam kegiatan pembelajaran. Hal ini terlihat saat guru menyampaikan salam pembuka, sebagian siswa menjawab salam guru. Pada saat guru memberikan pertanyaan, sebagian siswa aktif menjawab pertanyaan guru. Begitu pula saat guru menyampaikan langkah - langkah $P B L$, sebagian siswa memperhatikan guru.

Tahap mengorientasi peserta didik terhadap masalah Tahap ini dilakukan selama 10 menit dari jam 09.40 09.50. Pada saat guru memberikan motivasi atau rangsangan kepada siswa untuk memusatkan perhatian pada topik materi sistem pernapasan, sebagian siswa memperhatikan motivasi yang disampaikan guru.

Pada saat guru mengarahkan siswa untuk mempraktekkan apa yang dilakukan guru, sebagian anggota kelompok melaksanakan dan menuliskan poin poin permasalahannya.Tahap mengorganisasi siswa untuk belajar

Tahap ini dilakukan selama 10 menit dari jam $10.00-$ 10.10. Pada saat guru mengarahkan siswa untuk mencari hipotesis, semua anggota kelompok bekerjasama mencari dan menuliskan hipotesis berdasarkan rumusan masalah yang ditemukan.

Tahap mengorganisasi siswa untuk belajar

Tahap ini dilakukan selama 20 menit dari jam 10.10 - jam 10.30. Pada saat guru membimbing siswa dalam kelompok untuk berdiskusi, semua siswa berdiskusi untuk mencari data informasi mengenai struktur organ, fungsi, dan mekanisme pernapasan dan berusaha untuk menemukan solusi yang tepat.

Tahap mendukung kelompok investigasi

Tahap ini dilakukan selama 15 menit dari jam 10.50 - jam 11.05. Pada saat guru membimbing siswa dalam kelompok untuk berdiskusi, semua siswa berdiskusi untuk mencari data informasi mengenai pencemaran lingkungan yang terjadi di sekitarnya dan berusaha untuk menemukan solusi yang tepat. 
Tahap mengembangkan dan menyajikan artefak dan memamerkannya

Tahap ini dilakukan selama 20 menit dari jam 10.30 - jam 10.40. Pada saat guru mengarahkan siswa untuk membuat point-point kesimpulan dan mempresentasikan didepan kelas.

Tahap menganalisis dan mengevaluasi proses pemecahan masalah

Tahap ini dilakukan selama 10 menit dari jam 11.40 - jam 11.50. Pada saat guru mengarahkan siswa untuk memverifikasi hasil diskusi dengan literatur dan mengkonsultasikan kepada guru, sebagian kelompok mengkonsultasikan hasil diskusi kepada guru.

Pada saat kegiatan presentasi, siswa interaktif terutama kelompok 1 dan 4 mereka memperhatikan saat kelompok lainnya melakukan presentasi. Pada akhir pembelajaran siklus I yaitu kegiatan penutup, Kegiatan penutup ini dilakukan selama 10 menit dari jam 11.50 - 12.00. Siswa mengerjakan soal post test selama 10 menit.

Setelah menerapkan model $P B L$ dilakukan evaluasi untuk mengetahui hasil belajar kognitif siswa. Dari hasil yang diperoleh pada siklus I dapat diketahui bahwa siswa yang memperoleh nilai 70 dan dinyatakan tuntas hanya ada 11 siswa (47\%) dan yang belum tuntas ada 12 siswa $(53 \%)$, hal ini menunjukkan bahwa hasil ketuntasan belajar belum memenuhi indikator keberhasilan yaitu $80 \%$, dapat dilihat pada gambar 2 .

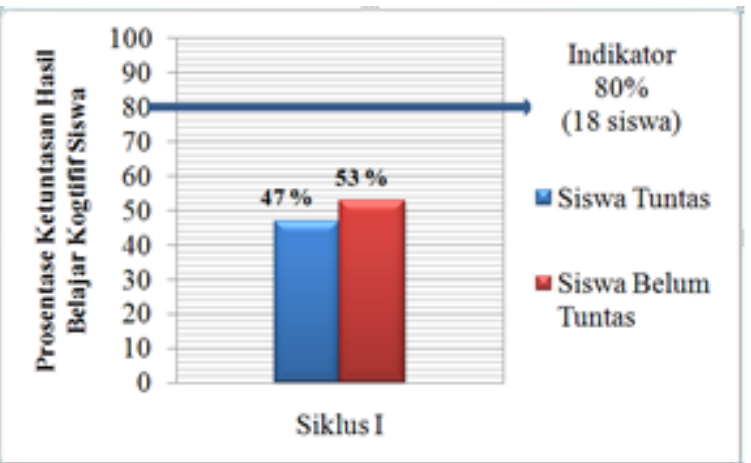

Gambar 2. Diagram Batang Ketuntasan Hasil Belajar Kognitif Siswa Siklus I

Karena siklus I belum mencapai indikator keberhasilan, maka guru dan peneliti melakukan perbaikan guna mengoptimalkan hasil pembelajaran pada siklus II.

\section{Siklus II}

Siklus II dilaksanakan dalam pada Kamis, 16Mei 2019. Dengan alokasi waktu 2 × 45 menit pada jam ke $1 \quad(07.30$ - 08.15) dan jam ke 2 (08.15 - 09.00). Materi yang disampaikan adalah volume udara pernapasan, mekanisme pertukaran oksigen dan karbondioksida, dan energi pernapasan pada manusia.Proses pembelajaran dilakukan oleh guru biologi dan peneliti menggunakan dua observer sebagai pengamat dalam proses pembelajaran. Adapun rincian pembelajarannya sebagai berikut:

Kegiatan pertama adalah pendahuluan ini dilakukan selama 10 menit dari jam 07.30 - 07.40. Pada kegiatan pendahuluan semua siswa menjawab salam guru dan berdoa untuk memulai pembelajaran, meskipun masih ada satu dua yang ramai. Saat guru memberikan pertanyaan, semua siswa menjawab pertanyaan guru. Saat guru menjelaskan langkah - langkah $P B L$, siswa sudah fokus memperhatikan guru dan memahami langkah $P B L$ karena sudah terbiasa dari siklus I.

Tahap mengorientasi peserta didik terhadap masalah Tahap ini dilakukan selama 10 menit dari jam 07.40 07.50. Pada saat guru memberikan motivasi atau rangsangan kepada siswa untuk memusatkan perhatian pada topik materi volume udara pernapasan, mekanisme pertukaran oksigen dan karbondioksida, dan energi pernapasan pada manusia, semua siswa mendengarkan motivasi yang disampaikan guru.

Pada saat guru mengarahkan siswa untuk menulis poin - poin permasalahan hasil diskusi, semua siswa menuliskan poin - poin permasalahan hasil diskusi dengan kelompoknya. Materi diskusi tiap kelompok meliputi volume udara pernapasan, mekanisme pertukaran oksigen dan karbondioksida, dan energi pernapasan pada manusia. Tahap mengorganisasi siswa untuk belajar

Tahap ini dilakukan selama 10 menit dari jam 07.50 - jam 08.00. Pada saat guru membagi kelompok mengarahkan siswa untuk mencari hipotesis berdasarkan rumusan masalah, semua siswa menulis dasar teori sesuai dengan rumusan masalah dari hasil diskusi dengan kelompoknya. Karena hal ini sudah sesuai, maka ketegasan guru harus dipertahankan.

Tahap mendukung kelompok investigasi

Tahap ini dilakukan selama 20 menit dari jam 08.00 - jam 08.20. Pada saat guru membimbing siswa dalam kelompok untuk berdiskusi mengenai materi, semua siswa berdiskusi mencari informasi, memecahkan masalah dan solusi. Karena, hal ini sudah sesuai dengan rencana kegiatan pembelajaran, maka ketegasan guru harus dipertahankan.

\section{Tahap mengembangkan dan menyajikan artefak dan} memamerkannya

Tahap ini dilakukan selama 20 menit dari jam 08.20 - jam 08.40. Pada saat guru mengarahkan siswa untuk menulis poin-poin hasil diskusi, semua anggota kelompok sudah tidak mengalami kesulitan dalam menulis poin-poin hasil diskusi, karena sudah mulai terbiasa dari pertemuan siklus I. Tapi guru belum bisa mengelola waktu dengan baik, dikarenakan yang seharusnya selesai jam 08.40 tapi jam 08.50 baru selesai. Karena, hal ini belum sesuai dengan rencana kegiatan pembelajaran, maka guru harus bisa mengelola waktu lebih baik lagi.

Tahap menganalisis dan mengevaluasi proses pemecahan masalah

Tahap ini dilakukan selama 20 menit dari jam 08.5009.10. Pada saat guru mengarahkan siswa untuk memverifikasi hasil diskusi dengan literatur dan mengkonsultasikan kepada guru. Semua kelompok sudah mengkonsultasikan hasil diskusi kepada guru sebelum melakukan presentasi.

Pada saat kegiatan presentasi, semua siswa aktif tanya jawab, meskipun masih ada satu dua siswa yang tidak berani mengajukan pertanyaan. Berdasarkan hasil post test siklus II secara individu adalah jumlah siswa yang 
mendapatkan nilai tuntas KKM (70) sebanyak 15 siswa atau $65 \%$, dapat dilihat pada gambar 3 .

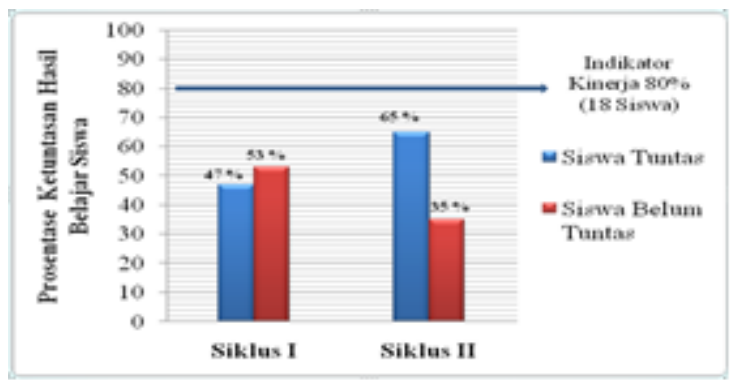

Gambar 3. Diagram Batang Ketuntasan Hasil Belajar Kognitif Siswa Siklus II

\section{Siklus III}

Siklus III dilaksanakan dalam pada jum'at, 17 Mei 2019. Dengan alokasi waktu 2 x 45 menit pada jam ke $1(07.30$ - 08.15) dan jam ke 2 (08.15 - 09.00). Materi yang disampaikan adalah faktor yang mempengaruhi frekuensi dan gangguan sistem pernapasan pada manusia. Proses pembelajaran dilakukan oleh guru biologi Ibnu Fadhlianto, S.Pd dan peneliti menggunakan dua observer sebagai pengamat dalam proses pembelajaran. Adapun rincian pembelajarannya sebagai berikut:

Kegiatan pendahuluan ini dilakukan selama 10 menit dari jam 07.30 - 07.40. Pada kegiatan pendahuluan semua siswa menjawab salam guru dan berdoa untuk memulai pembelajaran, meskipun masih ada satu dua yang ramai. Saat guru memberikan pertanyaan, semua siswa menjawab pertanyaan guru. Saat guru menjelaskan langkah - langkah $P B L$, siswa sudah fokus memperhatikan guru dan memahami langkah $P B L$ karena sudah terbiasa dari siklus I.

Tahap mengorientasi peserta didik terhadap masalah

Tahap ini dilakukan selama 10 menit dari jam 07.40 07.50. Pada saat guru memberikan motivasi atau rangsangan kepada siswa untuk memusatkan perhatian pada topik materi faktor yang mempengaruhi sistem pernapasan serta gangguan pernapasan pada manusia, semua siswa mendengarkan motivasi yang disampaikan guru.

Pada saat guru mengarahkan siswa untuk menulis poin - poin permasalahan hasil diskusi, semua siswa menuliskan poin - poin permasalahan hasil diskusi dengan kelompoknya. Materi diskusi tiap kelompok meliputi faktor yang mempengaruhi sistem pernapasan serta gangguan pernapasan pada manusia.

Tahap mengorganisasi siswa untuk belajar

Tahap ini dilakukan selama 10 menit dari jam 07.50 - jam 08.00. Pada saat guru membagi kelompok mengarahkan siswa untuk mencari hipotesis menganalisisdengan kelompoknya. Karena hal ini sudah sesuai, maka ketegasan guru harus dipertahankan.

Tahap mendukung kelompok investigasi

Tahap ini dilakukan selama 20 menit dari jam 08.00 - jam 08.20. Pada saat guru membimbing siswa dalam kelompok untuk berdiskusi mengenai materi, semua siswa berdiskusi mencari informasi, memecahkan masalah dan solusi. Karena, hal ini sudah sesuai dengan rencana kegiatan pembelajaran, maka ketegasan guru harus dipertahankan.

Tahap mengembangkan dan menyajikan artefak dan memamerkannya

Tahap ini dilakukan selama 20 menit dari jam 08.20 - jam 08.40. Pada saat guru mengarahkan siswa untuk menulis poin-poin hasil diskusi, semua anggota kelompok sudah tidak mengalami kesulitan dalam menulis poin-poin hasil diskusi, karena sudah mulai terbiasa dari pertemuan siklus II. Karena hal ini sudah sesuai, maka ketegasan guru harus dipertahankan.

Tahap menganalisis dan mengevaluasi proses pemecahan masalah

Tahap ini dilakukan selama 20 menit dari jam 08.50 09.10. Pada saat guru mengarahkan siswa untuk memverifikasi hasil diskusi dengan literatur dan mengkonsultasikan kepada guru. Semua kelompok sudah mengkonsultasikan hasil diskusi kepada guru sebelum melakukan presentasi.

Pada saat kegiatan presentasi, semua siswa aktif tanya jawab, meskipun masih ada satu dua siswa yang tidak berani mengajukan pertanyaan.

Berdasarkan hasil post test siklus III secara individu adalah jumlah siswa yang mendapatkan nilai tuntas KKM (70) sebanyak 19 siswa atau $83 \%$, dapat dilihat pada gambar 4.

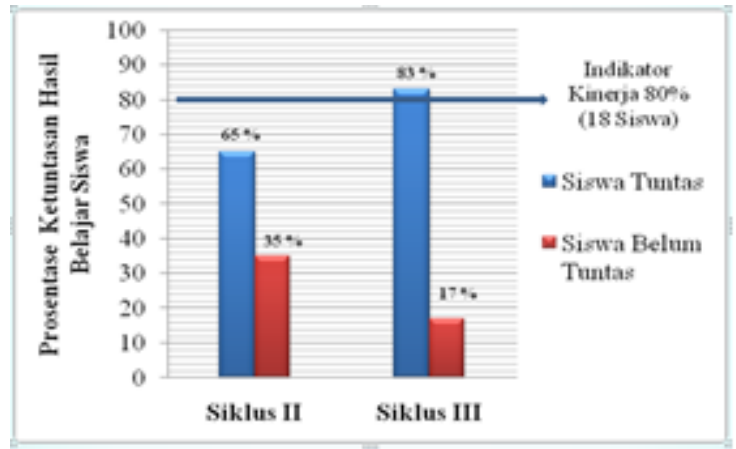

Gambar 4. Diagram Batang Ketuntasan Hasil Belajar Kognitif Siswa Siklus III

Dengan demikian dapat disimpulkan bahwa kegiatan pembelajaran siklus III dengan model $P B L$ terjadi peningkatan. Hal-hal yang merupakan kelemahan siklus I dan II sudah dapat teratasi pada siklus III. Guru sudah dapat menguasai kelas, sehingga semua siswa aktif dan fokus dalam belajar, meskipun masih ada 12 siswa yang ramai. Karena siklus III sudah mencapai indikator keberhasilan tindakan, sehingga penelitian dihentikan pada siklus III. Data hasil penelitian terhadap hasil belajar kognitif biologi siswa dapat dilihat pada tabel 1 . 
Tabel 1. Hasil Belajar Biologi dari Aspek Kognitif

\begin{tabular}{ccc}
\hline Siklus & $\begin{array}{c}\text { Persentase Ketuntasan } \\
\text { Hasil Belajar Kognitif }\end{array}$ & $\begin{array}{c}\text { Indikator } \\
\text { Keberhasilan } \\
\text { Ketuntasan }\end{array}$ \\
\hline I & $47 \%$ & Tidak Tuntas \\
II & $65 \%$ & Tidak Tuntas \\
III & $83 \%$ & Tuntas \\
\hline
\end{tabular}

Berdasarkan tabel 1, hasil belajar kognitif biologi mengalami peningkatan setiap siklusnya. Hasil yang diperoleh dari pembelajaran siklus I sampai dengan siklus III yaitu, siklus I sebesar $47 \%$, siklus II $65 \%$, dan siklus III $83 \%$ dengan indikator ketuntasan yang ditetapkan dalam penelitian ini minimal $80 \%$ yaitu 18 dari 22 siswa. Ketika siswa bertanggung jawab dan aktif dalam kegiatan diskusi, menemukan gagasan dan solusi dalam pemecahan masalah, mereka dapat lebih mudah memahami dan mengetahui permasalahan yang mereka pelajari dan ketika dihadapkan dengan tes, mereka dapat mengerjakan soal tes dengan benar.

Hal ini sesuai dengan pernyataan (Yuan, 2008) Model $P B L$ membantu siswa mengembangkan ilmunya dengan mencari informasi, pada saat siswa berdiskusi mereka bertanggung jawab terhadap penyelesaian masalah. Selain itu juga dalam model $P B L$ siswa di tuntut untuk bekerja sama dalam kelompok dan berfikir kritis. Hal ini sesuai dengan pernyataan

Pendapat lain pendapat Curry dalam Sungur (2006) mengatakan bahwa model PBL dapat menimbulkan kemampuan berpikir kritis dan pengetahuan baru yang berguna untuk jangka panjang

Dalam penelitian yang dilakukan oleh Setyorini. U; Sukiswo; Subali (2011). Model (PBL) mengajak siswa agar mampu melatih kemampuan siswa dalam memecahkan masalah sehingga dapat meningkatkan kemampuan berpikir kritis siswa. Tujuan penelitian ini adalah untuk mengetahui penerapan model Problem Based Learningpada sub pokok bahasan gerak lurus berubah beraturan yang dapat meningkatkan kempuan berpikir kritis siswa.

Dengan demikian dari pembahasan dan data-data yang disajikan, maka dapat disimpulkan bahwa model $P B L$ dapat meningkatkan aktivitas belajar dan hasil belajar siswa kelas XI MIPA SMA Veteran I Sukoharjo. Hal ini sesuai dengan penelitian Setyorini, Sukiswo, Subali (2011); Fauzan, Gani, Syukri (2017); Wasonowati, Redjeki, \& Ariani. (2014); Nafiah, \& Suyanto (2014) tentang penerapan model Problem Based Learning dapat meningkatkan aktivitas dan hasil belajar siswa, dan sangat penting dalam menunjang peningkatan kinerja peserta didik saat mengikuti pelajaran. Selain itu, penelitian dari Nafiah \& Suyanto (2014); Devi (2012); Dewi, Akbari, \& Nugroho (2019); Wasonowati, Redjeki, \& Ariani. (2014); Wulansari, Hanik, \& Nugroho (2019) menyatakan bahwa $P B L$ dapat meningkatkan ketrampilan berfikir kritis, aktivitas belajar dan hasil belajar siswa.

\section{KESIMPULAN}

Berdasarkan kegiatan penelitian tindakan kelas yang dilakukan di kelas XI MIPA SMA Veteran 1 Sukoharjo Tahun Pelajaran 2018/2019, maka dapat diambil kesimpulan bahwa "Penerapan model Problem Based Learning dapat meningkatkan aktivitas belajar dan hasil belajar biologi siswa pada materi pembelajaran sistem pernapasan pada kelas XI MIPA SMA Veteran 1 Sukoharjo Tahun Pelajaran 2018/2019"

Pada pembelajaran PBL diharapkan lebih kreatif, inovatif dan menggunakan media ajar dalam penerapan model Problem Based Learning (PBL) sesuai dengan materi pelajaran, sehingga tujuan pembelajaran dapat tercapai.

\section{UCAPAN TERIMA KASIH}

Penelitian ini dapat selesai dengan baik karena bantuan dari berbagai pihak. Oleh karena itu penulis mengucapkan terima kasih kepada SMA Veteran 1 Sukoharjo, yang telah banyak membantu dalam penelitian serta siswa kelas XI MIPA SMA Veteran 1 Sukoharjo Tahun Pelajaran $2018 / 2019$.

\section{DAFTAR PUSTAKA}

Devi, D. S. (2012). Penerapan Model Problem Based Learning (PBL) Untuk Meningkatkan Kemampuan Berpikir Kritis Peserta Didik Pada Pembelajaran IPA Kelas VIII SMP Negeri 5 Sleman.

Dewi, E. H. P., Akbari, S., \& Nugroho, A. A. (2019). Peningkatan Aktivitas dan Hasil Belajar Biologi melalui Model Problem Based Learning (PBL) pada Materi Pencemaran Lingkungan Siswa Kelas X SMA Negeri 1 Jatisrono. Journal of Biology Learning, $1(1)$.

Fauzan, M., Gani, A., Syukri, M. (2017). Penerapan model problem based learning pada pembelajaran materi sistem tata surya untuk meningkatkan hasil belajar siswa. Jurnal Pendidikan Sains Indonesia, 5(1), 27-35.

Fathurrohman, M. (2015). Model-model Pembelajaran Inovativ. Yogyakarta: Ar-Ruzz Media.

Sudjoko. 2001. Petunjuk Kegiatan Pembelajaran Mikro. Fakultas Matematika dan Ilmu Pengetahuan Alam.UNY.Yogyakarta.

Sungur Semra \& Ceren Tekkaya. 2006. Effect of Problem Based Learning and Traditional Instruction on Self Regulated Learning. The Journal of Educational Research, 99 (5): 316Suprijono, A. (2009). Cooperative Learning Teori dan Aplikasi PAIKEM. Yogyakarta: Pustaka Pelajar.

Nafiah, Y. N., \& Suyanto, W. (2014). Penerapan model problem-based learning untuk meningkatkan keterampilan berpikir kritis dan hasil belajar siswa. Jurnal Pendidikan Vokasi, 4(1).

Setyorini, U., Sukiswo, S. E., \& Subali, B. (2011). Penerapan model problem based learning untuk meningkatkan kemampuan berpikir kritis siswa SMP. Jurnal Pendidikan Fisika Indonesia, 7(1). 
Wasonowati, R. R. T., Redjeki, T., \& Ariani, S. R. D. (2014). Penerapan Model Problem Based Learning (PBL) pada Pembelajaran Hukum-Hukum Dasar Kimia Ditinjau dari Aktivitas dan Hasil

Wulansari, B., Hanik, N. R., \& Nugroho, A. A. (2019). Penerapan Model Problem Based Learning (PBL) disertai Mind Mapping untuk Meningkatkan Hasil Belajar pada Siswa Kelas X SMA Negeri 1 Tawangsari. Journal of Biology Learning, 1(1).

Yuan et. al. 2008. Promoting Critical Thinking Skill through Problem Based Learning. CMU. Journal of Soc. Sci. And Human,2 (2): 85-100 